Article

\title{
Life Cycle Assessment of Thai Hom Mali Rice to Support the Policy Decision on Organic Farming Area Expansion
}

\author{
Rattanawan Mungkung ${ }^{1,2, * \mathbb{C} \text {, Saruda Sitthikitpanya }}{ }^{1}$, Sarocha Dangsiri ${ }^{1}$ and \\ Shabbir H. Gheewala ${ }^{3,4}$ (1) \\ 1 Centre of Excellence on enVironmental Strategy for GREEN Business (VGREEN), Faculty of Environment, \\ Kasetsart University, Bangkok 10900, Thailand; saruda.sya@gmail.com (S.S.); \\ sarocha.dangsiri@gmail.com (S.D.) \\ 2 Department of Environmental Technology and Management, Faculty of Environment, Kasetsart University, \\ Bangkok 10900, Thailand \\ 3 The Joint Graduate School of Energy and Environment (JGSEE), King Mongkut's University of Technology \\ Thonburi (KMUTT), Bangkok 10140, Thailand; shabbir_g@jgsee.kmutt.ac.th \\ 4 Centre of Excellence on Energy Technology and Environment, PERDO, Ministry of Higher Education, \\ Science, Research and Innovation, Bangkok 10140, Thailand \\ * Correspondence: rattanawan.m@ku.th
}

Received: 23 June 2020; Accepted: 24 July 2020; Published: 26 July 2020

\begin{abstract}
Thailand has a strategic national policy to increase organic rice farming. This study firstly applied Life Cycle Assessment for evaluating the quantitative environmental impacts at the regional and national levels to facilitate the national policy decision on the expansion of organic rice cultivation areas. The impact categories of interest included global warming, terrestrial acidification, freshwater eutrophication, terrestrial ecotoxicity, and freshwater ecotoxicity, and the life cycle impact assessment method applied was ReCiPe. The results showed that the life cycle environmental impacts from organic rice cultivation in the nine provinces in the North were lower than those from the 12 provinces in the Northeast, due mainly to the higher yields and lower use of fertilizers in the former. The methane emissions in the North $\left(11,147 \mathrm{~kg} \mathrm{CO}_{2} \mathrm{e} / \mathrm{ha}\right)$ were similar to those in the Northeast $(11,378 \mathrm{~kg} \mathrm{CO} 2 \mathrm{e} / \mathrm{ha})$. However, nitrous oxide emissions in the Northeast were higher than in the North due to the higher amounts of fertilizer used. If Thailand expands the rice farming by $50 \%$ in the North and by $50 \%$ in the Northeast, the greenhouse gas emissions could be reduced from 11,400 to $11,100 \mathrm{~kg} \mathrm{CO}_{2} \mathrm{e} / \mathrm{ha}$, but the impacts of terrestrial acidification, freshwater eutrophication, terrestrial ecotoxicity, and freshwater ecotoxicity could be increased by $0.0257 \mathrm{~kg} \mathrm{PO}_{4} \mathrm{e}(95 \%), 0.508 \mathrm{~kg}$ 1,4-DBe (53\%), and $33.1 \mathrm{~kg} 1,4-\mathrm{DBe}(17 \%)$, respectively. To reduce the global warming as well as other environmental impacts, Thailand should expand rice farming areas to the North. This information could be useful for supporting the policy decisions on which areas the organic rice farming should be expanded in to minimize the potential life cycle environmental impacts.
\end{abstract}

Keywords: Hom Mali rice; organic rice; Life Cycle Assessment; policy decision; Thailand

\section{Introduction}

The World Food Summit Plan of Action has made a commitment on sustainable agriculture using appropriate technologies, such as organic farming to promote agro-ecosystem health, sustainable use of water and soil, and food security [1]. In 2018, there were 186 countries involved in organic farming, and total organic agricultural land expanded widely to 71.5 million hectares, especially in Europe and Asia, where the agricultural areas increased by about $9 \%$. The increase in organic agriculture promoted 
high values of the organic products with 96.7 billion euros for total consumption and 12.8 euros per capita consumption [2]. In Asia, the area used for organic agriculture is 6.5 million hectares, and the key crop is organic rice, representing $41 \%$ of the total organic cereal area [3]. In terms of organic agricultural area, Thailand was ranked seventh, and second in terms of production quantity. Thailand has the largest concentration of rice growers certified through United States Department of Agriculture [4].

Organic rice is becoming highly consumed because there is increasing preference worldwide for food and environmental sustainability [5]. In the organic farming system, almost all synthetic inputs are prohibited, and soil-building crop rotations are practiced. There are many advantages of the organic farming system over the conventional farming system. Firstly, organic farming enhances soil capacity for nutrient and water retention [6]. For example, soils under organic agriculture gain the characteristic of capturing more water and increasing water retention in the rhizosphere compared to soils under conventional treatment. It was shown that in the rainy season, water capture in organic areas could be $100 \%$ higher than in conventional areas [7]. Secondly, organic farming has better nutrient-retentive abilities and provides great biodiversity of microorganisms, insects, plants, and animals [6]. Organic agriculture also improved soil nutrients and enhanced microbiological activities (e.g., increases in total nitrogen content in soil (69-125\%), nitrate (42-174\%), phosphate $(47-116 \%)$, total microbial cells (38-127\%), and enzymatic activities (20-246\%) of acid phosphatase, protease, and dehydrogenase) [8,9]. Thirdly, organic farming can reduce the risk of infiltration and groundwater pollution from synthetic fertilizers and pesticides [6]. Lastly, the consumers gain the benefit of healthy food because the organic farming practices reduce pesticide use and utilize organic nutrient sources [6].

Organic rice cultivation is also known to enhance the soil organic carbon. Organic farming could potentially mitigate greenhouse gas (GHG) emissions via soil nutrient management practices. Komatsuzaki et al. [10] compared the carbon sequestration between conventional and organic rice production in West Java, Indonesia, and found that the soil in the organic farming system showed higher soil carbon content than conventional soils after four years of continuous organic farming; however, there were no significant differences in soil bulk density between the two farming systems. Minasny et al. [11] reported that the top $15 \mathrm{~cm}$ of soils stored about $31 \mathrm{Tg}$ of carbon (C) with a sequestration rate of $0.3 \mathrm{Tg} \mathrm{C}$ per year in South Korea, whereas the agricultural top soils accumulated more than $1.7 \mathrm{Tg}$ C per year in Java over the period 1990-2010. In China, it was estimated that the full popularization of straw return in China's rice paddies could sequester $10.48 \mathrm{Tg} C$ per year [12]. The effects of organic amendments on soil carbon sequestration in paddy fields of subtropical China were studied by Zhang et al. [13], who concluded that organic amendments increased soil organic carbon significantly by $7-45 \%$ after $25-28$ years of fertilization. The carbon was sequestered at a rate of 0.20 to 0.48 tha $^{-1}$ year $^{-1}$ under the double-rice and 0.70 to 0.88 tha $^{-1}$ year $^{1}$ under the rice-wheat cropping system. Ghimire et al. [14] highlighted that improved nutrient management practices, such as reduced- and no-tillage management, nitrogen $(\mathrm{N})$ fertilizer and farmyard manure (FYM) application, and crop residue addition, are important for increasing crop production as well as improving soil organic carbon sequestration.

As part of organic rice production sustainability, the environmental performance of organic and conventional rice cultivation systems has been intensively evaluated using Life Cycle Assessment (LCA). Yodkhum et al. [15] studied the GHG emissions from organic rice (Khao Dawk Mali 105) in the Chiang Mai province, Thailand. The total GHG emissions of organic rice production were $0.58 \mathrm{~kg} \mathrm{CO}_{2} \mathrm{e}$ per $\mathrm{kg}$ of paddy rice. The major source was the field emissions, which contributed $83 \%$ of the total GHG emissions, followed by field preparation, harvesting, and other stages (planting, cultivation, and transport of raw materials), with $9 \%, 5 \%$, and 3\% of the total, respectively. The GHG emissions of organic paddy rice were considerably lower than those of conventional rice production due to the advantage of using organic fertilizers [15]. Transforming farm management strategies from conventional to organic approaches also improved the efficiency of reducing GHG, particularly the emissions from irrigation and resource utilization [16,17]. However, some studies suggested that organic rice production could 
lead to higher environmental impacts compared to conventional production. A five-year long-term LCA study in Japan revealed that organic rice increased environmental impacts in comparison to conventional farm in terms of global warming, acidification, eutrophication, and non-renewable energy [18]. Hokazono and Hayashi [19] aimed to compare crop rotation systems used in organic farming (organic rotation systems) with those of both conventional farming (conventional rotation systems) and continuous rice cropping systems in Japan, and concluded that organic rotation systems have the potential of being recommended as sustainable agricultural practices, in comparison with conventional rotation systems and continuous (organic and conventional) rice production systems. Moreover, Nunes et al. [20] compared the Global Warming Potential (GWP) of white and brown rice between minimal tillage and organic systems under the practices and climate conditions in the south of Brazil. The results showed that the highest value of GWP was observed for the organic white rice (equivalent to $35.53 \mathrm{~kg} \mathrm{CO} 2 \mathrm{e} / \mathrm{kg}$ of protein), followed by the organic brown rice (equivalent to $26.50 \mathrm{~kg} \mathrm{CO} 2 \mathrm{e} / \mathrm{kg}$ of protein), and minimal-tillage brown rice (equivalent to $20.91 \mathrm{~kg} \mathrm{CO} 2 \mathrm{e} / \mathrm{kg}$ of protein), whereas the lowest GWP (equivalent to $15.80 \mathrm{~kg} \mathrm{CO}_{2} \mathrm{e} / \mathrm{kg}$ of protein) was observed in minimal-tillage white rice [20]. Bacenetti et al. [21] conducted an LCA of organic rice cultivation with a cradle-to-field-gate boundary in a farm located in Pavia, Italy. The results identified the key hotspots contributing to environmental impacts, namely the methane emission from the flooded fields, the production of compost, the nitrogen emissions associated with the application of fertilizer, and the mechanization of the field operations. From the results, the substitution of organic compost with cattle manure was selected as a mitigation strategy to reduce the greenhouse gas (GHG) emissions by 13-51\% [21]. Lovarelli and Bacenetti [22] reported that the mechanical operations carried out during farming activities were responsible for GHG emissions by both fuel consumption and exhaust gases directly emitted into the air, as well as by the consumption of mineral and fossil resources for realization of materials (i.e., the processes of mineral extraction, energy use, and production for the materials that compose the tractor and implement). In addition, Fusi et al. [23] evaluated the environmental profile of paddy rice cultivation with different straw management scenarios (burial into the soil of the straw versus harvesting) by using LCA, and highlighted that the collection of the straw improves the environmental performance of rice. Mungkung et al. [24] also evaluated the environmental performance of Hom Mali organic rice production in the Surin province of Thailand using LCA. The study was focused on the practical methodologies of carbon, water, and biodiversity footprints aiming to support the environmental product declaration for international markets to enhance the competitiveness. A carbon footprint of $2.88 \mathrm{~kg} \mathrm{CO}_{2} \mathrm{e}$ per $\mathrm{kg}$ was observed, with a considerable water use index of $1.34 \mathrm{~m}^{3} \mathrm{H}_{2} \mathrm{Oe}$ [24].

In Thailand, organic rice is being promoted under a strategic national policy on sustainable agriculture and Thailand 4.0 due to a premium price from niche markets [25]. According to the National Economic and Social Development Plan (2017-2021), it is targeted that the organic agriculture area will be increased by $15 \%$ per year; $90 \%$ of this area is for rice [25]. In 2019, Thailand had around 91,265 hectares of agricultural area under organic cultivation, out of which $59 \%$ was used for organic rice production [26]. The main production sites for organic rice are in the Northeast (80\%) and the North (20\%) [27]. The goal of this study was, therefore, to analyze the environmental performance of organic rice cultivation in Thailand by using the LCA methodology. Different scenarios of organic rice farming expansion in the North and the Northeast of Thailand were proposed with the calculation of potential life cycle environmental impacts. Most of the studies reviewed in the literature have evaluated rice at the product level. This study is original in its use of LCA as an assessment tool to deliver the quantitative and potential life cycle environmental impacts at the regional and national levels to facilitate the national policy decisions on the expansion of organic rice cultivation areas in Thailand. 


\section{Materials and Methods}

\subsection{Goal and Scope Definition}

The studied organic rice is Hom Mali rice (KhaoDawk Mali 105), which is the main organic rice cultivated in Thailand. The method used for the LCA study followed the guidelines laid out in ISO14040 and $14044[28,29]$. The goal of this study was to assess the potential life cycle environmental impacts from expanding organic rice farming (160,000 hectares) [27]. The studied areas (Figure 1) covered the land areas identified by the Department of Land Development that are suitable for rice cultivation, located in 9 provinces in the North $(\mathrm{N})$ and 12 provinces in the Northeast (NE), namely: N1 (Maesai, Mueang, Pan, Mae Lao, and Chiang Sean districts, Chiang Rai province, Thailand), N2 (Dok Kham Tai, Baantoon, and Hong Hin districts, Phayao province, Thailand), N3 (Thoen and Mueang districts, Lampang province, Thailand), N4 (Mae Dang and Mae Rim districts, Chiang Mai province, Thailand), N5 (Keereemat and Ban Dan Lan Hoi districts, Sukhothai province, Thailand), N6 (Hat Kruat, Thasao, Hat Song Kwae, and Wang Din districts, Uttradit province, Thailand), N7 (Bang Mun Nak, Wachira Barami, Pho Thale, and Pho Prathap Chang districts, Phichit province, Thailand), N8 (Thap Than and Swang Arom districts, Uthai Thani province, Thailand), N9 (Mueang and Si Thep districts, Phetchabun province, Thailand), NE1 (Wanon Niwat, Waritchaphum, and Pang Khon districts, Sakon Nakhon province, Thailand), NE2 (Mueang and Don Tan districts, Mukdahan province, Thailand), NE3 (Kut Chum, Kho Wang, and Pa Tiu districts, Yasothon province, Thailand), NE4 (Mueang and Hua Ta Pan districts, Amnat Charoen province, Thailand), NE5 (Trakanphuetphon, Muang Samsip, Det Udom, Mueang, Khemmarat, Sam Rong, and Phibunmangsahan districts, Ubon Ratchathani province, Thailand), NE6 (Sikhoraphum and Khu Kan districts, Sisaket province, Thailand), NE7 (Chumphon Buri, Sikhoraphum, Chomphra, and Kap Choeng districts, Surin province, Thailand), NE8 (Chalerm Prakiat and Nongki districts, Buriram province, Thailand), NE9 (Mueang and Borabue districts, Maha Sarakham province, Thailand), NE10 (Mueang and Nakhu districts, Kalasin province, Thailand), NE11 (Waeng Yai, Phon, and Samsoong districts, Khon Kaen province, Thailand), NE12 (Phimai, Prathai, Bua Yai, and Sung Noen districts, Nakhon Ratchasima province, Thailand).

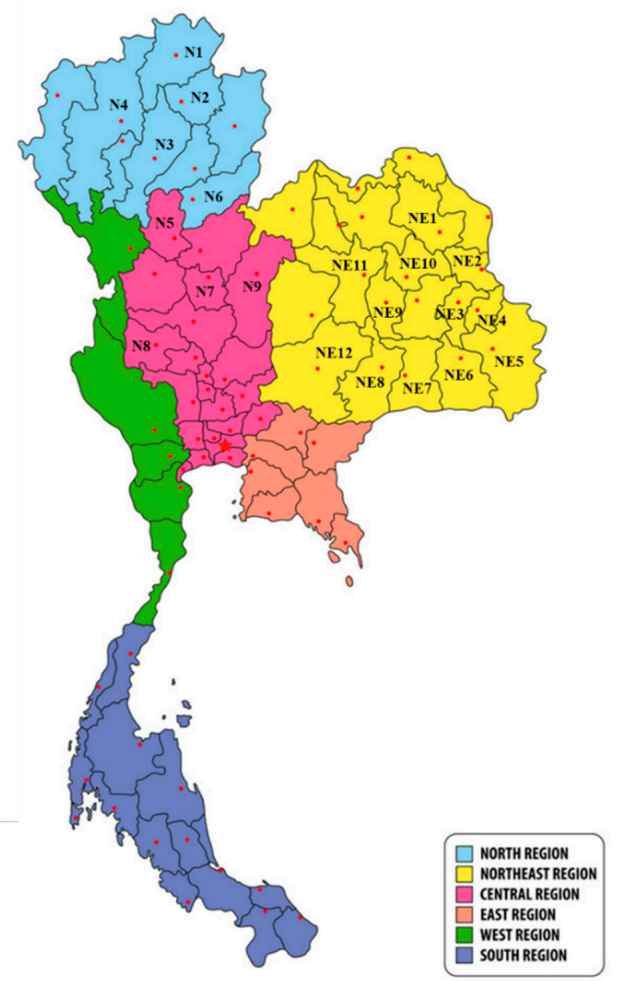

Figure 1. Potential areas for expanding organic rice cultivation. 
This study proposed alternative scenarios based on varying cultivation areas of organic rice farming in the North $(\mathrm{N})$ and Northeast $(\mathrm{NE})$ regions. The different cultivation area ratios were varied, as shown in Table 1, based on the assumptions that the proposed ratios were applied in all provinces for a particular region. Moreover, the average inputs and outputs were used as the representative datasets for a particular province.

Table 1. Alternative scenarios of organic rice area expansion.

\begin{tabular}{ccc}
\hline \multirow{2}{*}{ Scenarios } & \multicolumn{2}{c}{ Cultivation Area Ratios } \\
\cline { 2 - 3 } & North (N) & Northeast (NE) \\
\hline N100 & $100 \%$ & - \\
N80 + NE20 & $80 \%$ & $20 \%$ \\
N60 + NE40 & $60 \%$ & $40 \%$ \\
N50 + NE50 & $50 \%$ & $50 \%$ \\
N40 + NE60 & $40 \%$ & $60 \%$ \\
N20 + NE80 & $20 \%$ & $80 \%$ \\
NE100 & - & $100 \%$ \\
\hline
\end{tabular}

Note: Percentage is the ratio of cultivation area to the total cultivation area.

The system boundary in this study was defined as the organic rice product system based on cradle to farm gate, covering the field preparation activities (tilling, sowing, and fertilizing), the cultivation period (seeding, planting, and fertilizing), and the harvesting (Figure 2). The main rice species cultivated is jasmine rice, with the local name of Khao Dawk Mali 105 (KDML 105). The crop production cycle was 120 days. Agricultural machines (i.e., tractors) were used for land preparation (land excavation) and the petrol used for tractors was taken into account [22]. The organic rice seeds were mainly sourced from the local rice seed division, Department of Rice. For some provinces, the organic rice seeds were produced by a group of local farmers who were trained by the local rice seed division of the Department of Rice on the rice seed production and farming practices. These groups of farmers would provide their seeds to the farmers who grew the paddy rice, with a commitment to give the paddy rice back to the seed producers at the ratio of 1:3 (seed to paddy rice) at the harvesting time. Most of the rice fields in the North are within irrigated zones, whereas the rice fields in the Northeast totally rely on rainfall. During the cultivation period, organic fertilizers were added periodically, and biological extracts made from vegetable and fruit wastes were applied, if needed. Harvesting machines were generally used, but a proper cleaning system was required. The petrol used for harvesting machines was also considered [22]. After harvesting, the straw was usually incorporated into the soil together with manure for nutrient management to prepare a good soil quality for the next crop. Thus, there was no allocation in this case, and all environmental impacts were totally allocated to the paddy rice. The effect of straw management and soil quality on GHG emissions was beyond the scope of this LCA. The soil carbon in rice fields was also not included in the study, as rice has been planted in the region for a long time and, hence, no major changes were anticipated. The unit of analysis was set as 1 ha of organic rice cultivation to facilitate the comparison of environmental performances based on land use from the policy perspective. 


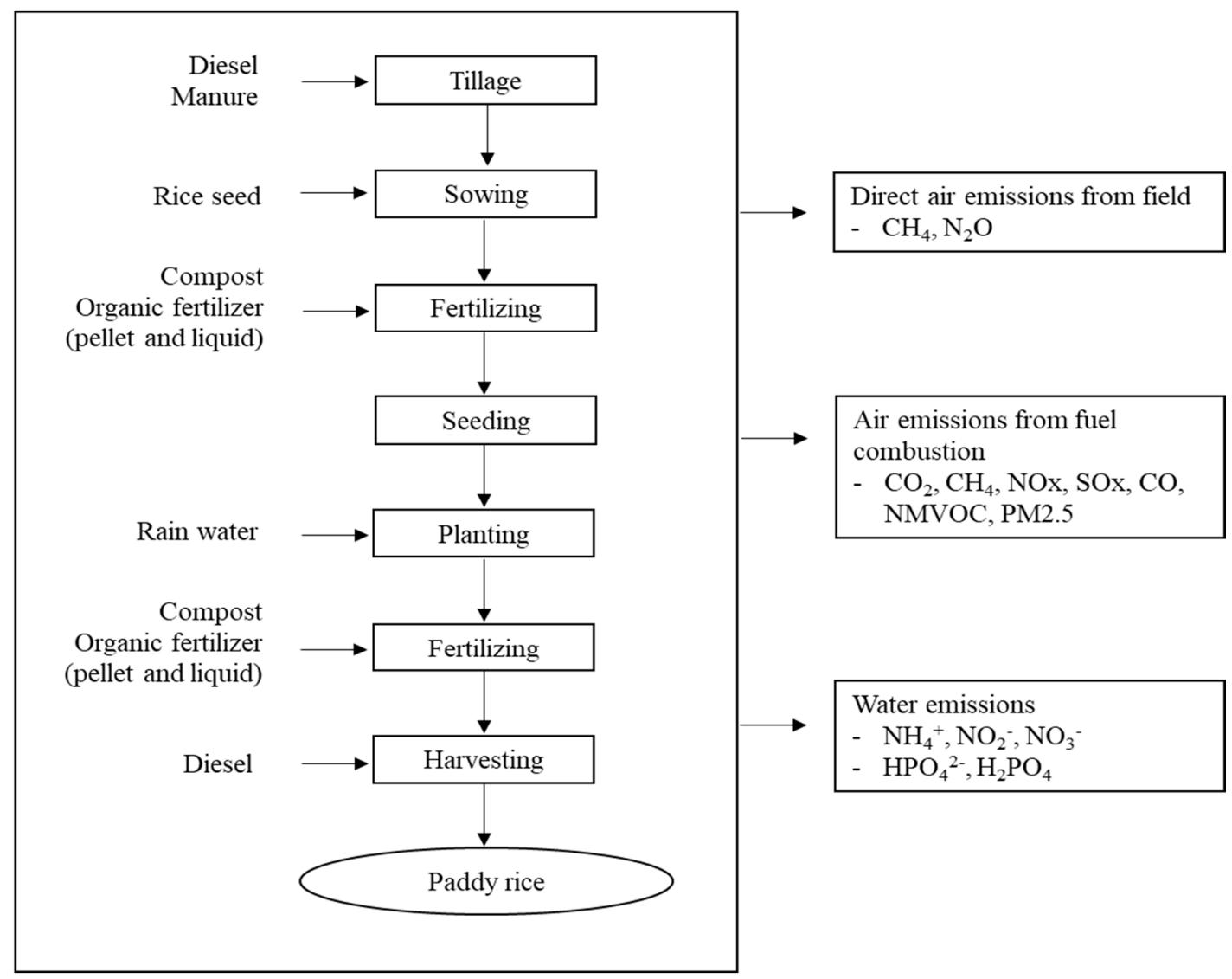

Figure 2. System boundary of the Life Cycle Analysis (LCA) study.

\subsection{Inventory Data Collection}

Based on the organic rice farming production in 2017, the inventory data were collected from 184 farmers covering 317 ha of the total cultivation area in the North and 208 farmers covering about 592 ha of the total cultivation area in the Northeast. The samples were selected based on the sampling of organic farms registered with the Department of Rice, Ministry of Agriculture and Cooperatives, Thailand. The required input and output data were identified as follows: (1) Inputs: Land, seed, fuel, water (rainfall), and organic fertilizers, and (2) Outputs: Paddy rice and emissions into the environment (including air and waterborne emissions). The inventory data (foreground data) were mainly collected from the direct interviewing of farmers. In organic farming practice, there were four types of organic fertilizers applied: Manure, compost, organic fertilizer (pellet), and organic fertilizer (liquid) with different levels of $\% \mathrm{~N}$ and $\% \mathrm{P}_{2} \mathrm{O}_{5}$ (Table 2). Agricultural machines were used for field preparation and harvesting activities, and the quantity of diesel used by the different machines was taken from the literature [30].

Table 2. Nutrient levels in different organic fertilizers.

\begin{tabular}{cccc}
\hline Organic Fertilizer & $\mathbf{\%} \mathbf{N}$ & $\mathbf{~}_{\mathbf{0}} \mathbf{P}_{\mathbf{2}} \mathbf{O}_{\mathbf{5}}$ & Sources of Data \\
\hline Manure & 1.9 & 0.7 & {$[31]$} \\
Compost & 2.6 & 0.9 & {$[32]$} \\
Organic fertilizer (pellet) & 1.75 & 1.66 & {$[33]$} \\
Organic fertilizer (liquid) & 0.25 & 0.05 & {$[34]$} \\
\hline
\end{tabular}

The GHG emissions from the organic rice fields under consideration are carbon dioxide, methane, and nitrous oxide. The direct GHG emissions from the organic rice field were based on the literature where available, and were supplemented by the default values as defined in the Product Category 
Rules (PCR) of rice products developed by the Thailand Greenhouse Gas Management Organization (Public Organization) (TGO) [30], which are based on the Intergovernmental Panel on Climate Change (IPCC) Tier-1 method [35]. The default values of direct GHG emissions were provided with the scaling factors associated with the major or second rice and the farm location in a particular region, including the water management (Table 3).

Table 3. Direct greenhouse gas (GHG) emissions from organic rice fields in the North and Northeast.

\begin{tabular}{ccc}
\hline \multirow{2}{*}{ Type of Rice Fields } & \multicolumn{2}{c}{$\mathrm{CH}_{\mathbf{4}}$ Emission/Season (120 Days) $\left(\mathrm{gCH}_{\mathbf{4}} / \mathbf{m}^{\mathbf{2}}\right)$} \\
\cline { 2 - 3 } & Irrigated Crop & Rainfed Crop \\
\hline Major rice & 45.38 & 30.41 \\
Second rice & 14.57 & - \\
\hline
\end{tabular}

Five different field emissions from rice fields were considered: (1) Direct emissions from the field and methane emissions from organic matter decomposition; (2) emissions from fertilizer application and nitrous oxide emissions from rice fields, including direct and indirect nitrous oxide emissions from managed soils; (3) emissions from fuel combustion into the air, which are carbon dioxide, methane, nitrogen dioxide, sulfur dioxide, carbon monoxide, non-methane volatile organic compounds (NMVOCs), and nitrous oxide; (4) phosphorus emission into water, leaching into the ground and run-off into surface water using a factor of $0.175 \mathrm{~kg} \mathrm{P} \mathrm{ha}^{-1}$ year $^{-1}$; and (5) nitrogen emissions into water, leaching into the ground and run-off into surface water (Table 4).

\subsection{Impact Assessment}

The life cycle impact assessment method was the ReCiPe 2016 Midpoint v 1.02 [36]. The impact categories of interest were selected based on the associated potential impacts and the policy context: Global warming as $\mathrm{kg} \mathrm{CO}_{2} \mathrm{e}$, terrestrial acidification as $\mathrm{kg} \mathrm{SO}_{2} \mathrm{e}$, freshwater eutrophication as $\mathrm{kg} \mathrm{PO}_{4} \mathrm{e}$, terrestrial ecotoxicity as $\mathrm{kg} 1,4-\mathrm{DCB}$, and freshwater ecotoxicity as $\mathrm{kg} 1,4-\mathrm{DCB}$. The impacts were evaluated using SimaPro version 8.5.2 with ecoinvent 3 databases supplementing the field data and other localized data from government sources and international literature (Table 4).

Table 4. Data sources of the inputs and outputs associated with organic rice farming.

\begin{tabular}{|c|c|c|}
\hline Inventory & Unit & Sources of Data \\
\hline Seed & $\mathrm{kg} \mathrm{ha}^{-1}$ & Farmer interviews \\
\hline Organic fertilizer & $\mathrm{kg} \mathrm{ha}^{-1}$ & Farmer interviews \\
\hline Diesel & $\mathrm{L} \mathrm{ha}^{-1}$ & [30] \\
\hline Rain water & $\mathrm{m}^{3} \mathrm{ha}^{-1}$ & [37] \\
\hline Emissions into air from direct field emission & $\mathrm{kg}$ & [35] \\
\hline $\begin{array}{l}\text { Emissions into air from fertilizer, atmospheric decomposition of } \\
\text { volatilized } \mathrm{N} \text {, leaching and runoff } \mathrm{N}\left(\mathrm{N}_{2} \mathrm{O}\right)\end{array}$ & $\mathrm{kg} \mathrm{ha}^{-1}$ & {$[35]$} \\
\hline Emissions to air from fossil fuel combustion & $\mathrm{kg} \mathrm{ha}^{-1}$ & {$[35,38]$} \\
\hline \multicolumn{3}{|c|}{ Emissions into air from fertilizer application } \\
\hline NOx & $\mathrm{kg} \mathrm{ha}^{-1}$ & [38] \\
\hline $\mathrm{NH}_{3}$ & $\mathrm{~kg} \mathrm{ha}^{-1}$ & [38] \\
\hline NMVOCs & $\mathrm{kg} \mathrm{ha}^{-1}$ & [38] \\
\hline \multicolumn{3}{|l|}{ Emissions into water } \\
\hline $\mathrm{N}$ output, $\mathrm{N}$ runoff & $\mathrm{kg} \mathrm{ha}^{-1}$ & [35] \\
\hline $\mathrm{P}$ leaching, $\mathrm{P}$ runoff & $\mathrm{kg} \mathrm{ha}^{-1}$ & [35] \\
\hline
\end{tabular}




\section{Results and Discussion}

\subsection{Inventory Analysis Results}

Table 5 shows the gate-to-gate inventory data of organic Hom Mali rice farming over the crop period of 120 days in the North and the Northeast. The average of the rice yield in the North (3267 $\mathrm{kg} / \mathrm{ha}$ ) was higher than that in the Northeast $(2946 \mathrm{~kg} / \mathrm{ha})$. The lower yield in the Northeast is mainly due to the lower fertility of soil [39]. Thus, higher fertilizer use (mainly compost, cattle manure, and liquid organic fertilizer) was observed in the Northeast. The rice cultivation in the Northeast also required more seeds per unit area compared to the North. The amount of rainwater in the Northeast was higher.

Table 5. Inventory data of organic rice farming in the North and the Northeast.

\begin{tabular}{|c|c|c|c|c|c|c|c|c|c|}
\hline \multirow[t]{2}{*}{ Farm } & Area & Yield & Seed & $\begin{array}{c}\text { Rain } \\
\text { Water }\end{array}$ & $\begin{array}{l}\text { Green } \\
\text { Manure }\end{array}$ & $\begin{array}{l}\text { Cattle } \\
\text { Manure }\end{array}$ & Compost & $\begin{array}{l}\text { Organic Fertilizer } \\
\text { (Pellet) }\end{array}$ & $\begin{array}{c}\text { Organic Fertilizer } \\
\text { (Liquid) }\end{array}$ \\
\hline & (ha) & (kg/ha) & (kg/ha) & $\left(\mathrm{m}^{3} / \mathrm{ha}\right)$ & (kg/ha) & (kg/ha) & (kg/ha) & (kg/ha) & (kg/ha) \\
\hline N1 & 19 & 3238 & 125 & 14,700 & 70 & 996 & 245 & 430 & 87 \\
\hline N2 & 38 & 3557 & 94 & 11,420 & - & 262 & 194 & 423 & 71 \\
\hline N3 & 51 & 3135 & 94 & 11,460 & - & 1074 & 149 & 518 & 6 \\
\hline N4 & 41 & 3317 & 75 & 10,640 & 313 & 398 & 103 & 831 & 8 \\
\hline N5 & 19 & 3646 & 94 & 12,130 & 677 & 1771 & 78 & 104 & 6 \\
\hline N6 & 44 & 3292 & 94 & 12,250 & 40 & 64 & 748 & 566 & 7 \\
\hline N7 & 55 & 2825 & 94 & 13,270 & 72 & 387 & 428 & 53 & 334 \\
\hline N8 & 37 & 3120 & 125 & 9870 & 53 & 1597 & 53 & 634 & 6 \\
\hline N9 & 13 & 3277 & 94 & 11,390 & 724 & 800 & 762 & 313 & 6 \\
\hline N-Avg & & 3267 & 99 & 11,903 & 217 & 817 & 307 & 430 & 59 \\
\hline NE1 & 16 & 2855 & 125 & 16,801 & - & 257 & 647 & 380 & - \\
\hline NE2 & 2 & 2813 & 125 & 12,431 & - & 1146 & 1354 & 0 & 208 \\
\hline NE3 & 72 & 2828 & 94 & 12,431 & - & 31 & 1454 & 14 & 14 \\
\hline NE4 & 45 & 2881 & 125 & 12,431 & 6 & 914 & 63 & 111 & 17 \\
\hline NE5 & 41 & 3035 & 125 & 18,810 & - & 1568 & 2094 & 345 & 19 \\
\hline NE6 & 128 & 2883 & 125 & 13,890 & 66 & 1001 & - & 219 & - \\
\hline NE7 & 211 & 2929 & 125 & 13,890 & 332 & 76 & 1684 & 3 & 1 \\
\hline NE8 & 18 & 2910 & 125 & 12,060 & - & 698 & 123 & 337 & 809 \\
\hline NE9 & 8 & 3163 & 125 & 14,937 & - & 31 & 1538 & 31 & 340 \\
\hline NE10 & 27 & 3129 & 94 & 13,770 & 110 & 1678 & 571 & 0 & 18 \\
\hline NE11 & 6 & 3172 & 125 & 9731 & - & 625 & 1031 & 0 & 1656 \\
\hline NE12 & 18 & 2755 & 94 & 9770 & - & 505 & 1326 & 163 & 33 \\
\hline NE-Avg & & 2946 & 117 & 13,413 & 43 & 711 & 990 & 134 & 260 \\
\hline
\end{tabular}

Note: N: North; NE: Northeast; Avg: Average. N1 (Chiang Rai), N2 (Phayao), N3 (Lampang), N4 (Chiang Mai), N5 (Sukhothai), N6 (Uttradit), N7 (Phichit), N8 (Uthai Thani), N9 (Phetchabun), NE1 (Sakon Nakhon), NE2 (Mukdahan), NE3 (Yasothon), NE4 (Amnat Charoen), NE5 (Ubon Ratchathani), NE6 (Sisaket), NE7 (Surin), NE8 (Buriram), NE9 (Maha Sarakham), NE10 (Kalasin), NE11 (Khon Kaen), NE12 (Nakhon Ratchasima).

The inventory of inputs per ha of the cultivation of organic rice and different field emissions is shown in Table 6. Similar direct emissions $\left(\mathrm{CH}_{4}\right)$ were found in the North and the Northeast. The nitrous oxide emissions from rice fields in the Northeast were higher than in the North due to the higher amounts of fertilizer used in the Northeast. The emissions from fossil fuel combustion into air, which are carbon dioxide, methane, nitrogen dioxide, sulfur dioxide, carbon monoxide, NMVOCs, and nitrous oxide, were higher in the Northeast because seeding in the Northeast is mechanized, whereas it is done manually in the North. The water emissions, including total nitrogen and total phosphorus, in the Northeast were also higher than those in the North because of the fertilizer used (Table 6). 
Table 6. Inventory of inputs and outputs per ha of the cultivation of organic rice (the crop period was 120 days).

\begin{tabular}{|c|c|c|c|}
\hline Inventory & Unit & North & Northeast \\
\hline Crop yield & $\mathrm{kg}$ & 3267 & 2946 \\
\hline Seed & $\mathrm{kg}$ & 99 & 117 \\
\hline Rain water & $\mathrm{m}^{3}$ & 11,903 & 13,413 \\
\hline Manure (green and cattle) & $\mathrm{kg}$ & 1034 & 754 \\
\hline Compost & $\mathrm{kg}$ & 307 & 990 \\
\hline Organic fertilizer (pellet and liquid) & $\mathrm{kg}$ & 489 & 394 \\
\hline Diesel & $\mathrm{L}$ & 26 & 39 \\
\hline \multicolumn{4}{|c|}{ Air emissions } \\
\hline Methane (field emission) & $\mathrm{kg}$ & 46.0 & 45.8 \\
\hline Nitrous oxide & $\mathrm{kg}$ & 0.1567 & 0.200 \\
\hline Nitrous oxide (indirect, volatilization) & $\mathrm{kg}$ & 0.0105 & 0.0133 \\
\hline Nitrous oxide (leaching/run off) & $\mathrm{kg}$ & 0.118 & 0.150 \\
\hline \multicolumn{4}{|c|}{ Air emissions (fossil fuel combustion) } \\
\hline Carbon dioxide & $\mathrm{kg}$ & 70.2 & 105 \\
\hline Methane & $\mathrm{kg}$ & 0.0028 & 0.0043 \\
\hline Nitrogen dioxide & $\mathrm{kg}$ & 0.0006 & 0.0009 \\
\hline Sulfur dioxide & $\mathrm{kg}$ & 0.775 & 1.16 \\
\hline Carbon monoxide & $\mathrm{kg}$ & 0.0077 & 0.0116 \\
\hline non-methane volatile organic compounds (NMVOCs) & $\mathrm{kg}$ & 0.0385 & 0.0577 \\
\hline Nitrous oxide & $\mathrm{kg}$ & 0.242 & 0.363 \\
\hline \multicolumn{4}{|c|}{ Water emissions } \\
\hline Total nitrogen & $\mathrm{kg}$ & 6.65 & 8.48 \\
\hline Total phosphorus & $\mathrm{kg}$ & 0.188 & 0.178 \\
\hline
\end{tabular}

\subsection{Life Cycle Impact Assessment}

Table 7 shows the life cycle impact assessment results of organic rice paddy production in the North and the Northeast. It was found that the organic rice paddy production in the North had lower impact on global warming but higher impact on freshwater eutrophication, terrestrial ecotoxicity, and freshwater ecotoxicity than that in the Northeast. The lower global warming impact of organic rice paddy production in the North was associated with the higher yield, lower fertilizer application, and lower diesel use for agricultural machines. However, the application of green manure and organic fertilizer (pellet) could potentially release reactive $\mathrm{N}$ and $\mathrm{P}$, leading to higher values of freshwater eutrophication for organic rice paddy production in the North.

Table 7. Life cycle impact assessment results of organic rice paddy production in the North and the Northeast.

\begin{tabular}{cccccc}
\hline \multirow{2}{*}{ Impact Categories } & \multirow{2}{*}{ Unit } & \multicolumn{2}{c}{ North } & \multicolumn{2}{c}{ Northeast } \\
\cline { 3 - 6 } & & Per kg & Per ha & Per kg & Per ha \\
\hline Global warming & $\mathrm{kg} \mathrm{CO}_{2} \mathrm{e}$ & 3.41 & 11,100 & 3.86 & 11,400 \\
Terrestrial acidification & $\mathrm{kg} \mathrm{SO}_{2} \mathrm{e}$ & 0.0011 & 3.80 & 0.0012 & 3.72 \\
Freshwater eutrophication & $\mathrm{kg} \mathrm{PO}_{4} \mathrm{e}$ & $2.40 \times 10^{-5}$ & 0.0783 & $9.17 \times 10^{-6}$ & 0.0270 \\
Terrestrial ecotoxicity & $\mathrm{kg} \mathrm{1,4-DBe}$ & 0.0796 & 260 & 0.0658 & 194 \\
Freshwater ecotoxicity & $\mathrm{kg} \mathrm{1,4-DBe}$ & 0.0006 & 1.98 & 0.0003 & 0.963 \\
\hline
\end{tabular}

Figure 3 shows the contribution analysis results of organic rice paddy production in the North (A) and the Northeast (B). The GHG emissions, especially from field emissions of methane, were the main contributor to the impact on global warming for both regions (93\% for the North, and $91 \%$ for the North East). In the North, the use of fertilizers (especially organic fertilizer (pellet)) was identified as 
the key contributor to environmental impacts, which contributed to $86 \%$ in terrestrial acidification, $98 \%$ in freshwater eutrophication, $68 \%$ in terrestrial ecotoxicity, and $94 \%$ in freshwater ecotoxicity. In the Northeast, the use of fertilizers (mainly organic fertilizer (pellet) and compost) also highly contributed to terrestrial acidification (80\%), freshwater eutrophication $(88 \%)$, and freshwater ecotoxicity $(81 \%)$. The use of diesel for agricultural machinery contributed substantially to terrestrial ecotoxicity (61\%).

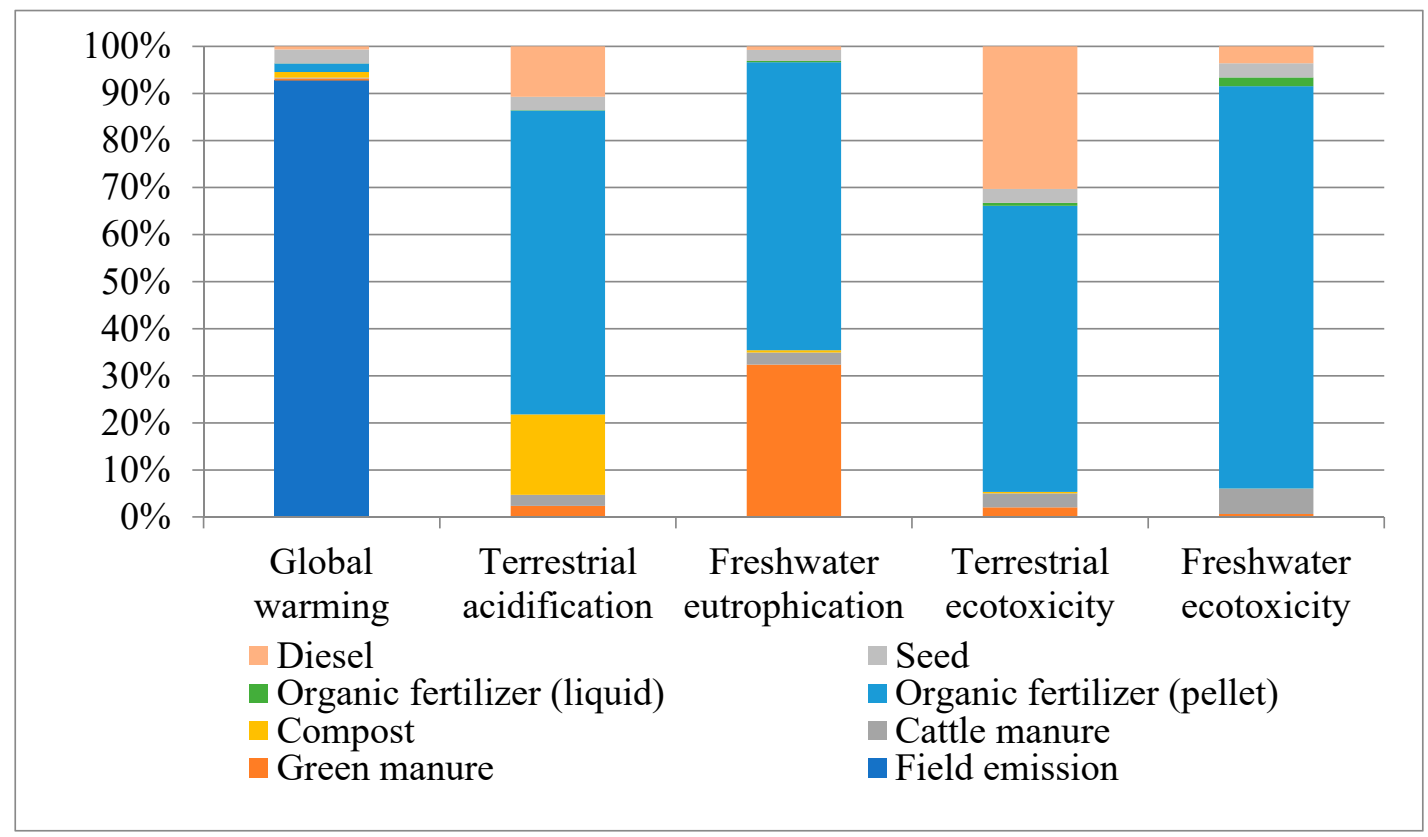

(A)

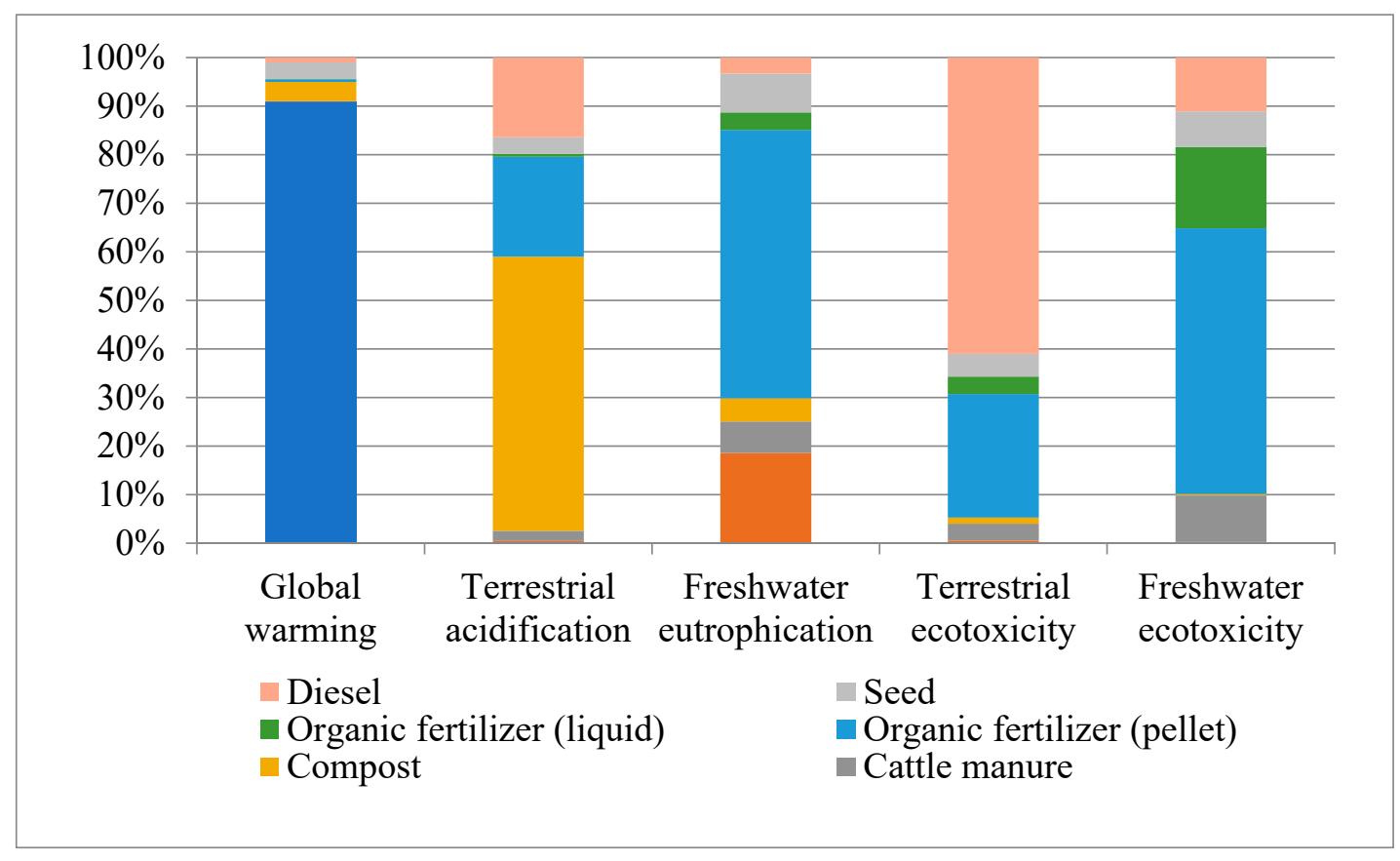

(B)

Figure 3. The contribution analysis results for organic rice paddy production in the North (A) and the Northeast (B). 


\subsection{Scenarios of Rice Farming Expansion}

Table 8 shows the life cycle impact assessment results of different scenarios of organic rice production as the consequences of rice farming expansion in the North and Northeast. Due mainly to the higher yield in the North with lower inputs (i.e., fertilizer), the expansion of organic rice farming totally in the North offered a lower impact on global warming. In contrast, the expansion of organic rice farming totally in the Northeast presented lower impacts on terrestrial acidification, freshwater eutrophication, terrestrial ecotoxicity, and freshwater ecotoxicity. To reduce global warming, Thailand should expand the rice farming area to the North. Nevertheless, Thailand should expand the area to the Northeast when considering soil and water pollution as a priority. For example, if Thailand expands the rice farming by $50 \%$ in the North and $50 \%$ in the Northeast, the global warming could be reduced from 11,400 to $11,100 \mathrm{~kg} \mathrm{CO}_{2} \mathrm{e}(1.02 \%)$, but the impacts of terrestrial acidification, freshwater eutrophication, terrestrial ecotoxicity, and freshwater ecotoxicity could increase by $0.0433 \mathrm{~kg} \mathrm{SO}_{2} \mathrm{e}$ (1.16\%), $0.0257 \mathrm{~kg} \mathrm{PO}_{4} \mathrm{e}(95 \%), 33.13 \mathrm{~kg}$ 1,4-DBe (17.2\%), and $0.5075 \mathrm{~kg}$ 1,4-DBe (52.7\%), respectively (Table 8). Therefore, the suitable scenario should be based on the consideration of impact categories.

Table 8. Life cycle impact assessment results of different scenarios of organic rice production as the consequences of rice farming expansion in the North and Northeast.

\begin{tabular}{cccccc}
\hline \multirow{2}{*}{ Scenario } & $\begin{array}{c}\text { Global } \\
\text { Warming }\end{array}$ & $\begin{array}{c}\text { Terrestrial } \\
\text { Acidification }\end{array}$ & $\begin{array}{c}\text { Freshwater } \\
\text { Eutrophication }\end{array}$ & $\begin{array}{c}\text { Terrestrial } \\
\text { Ecotoxicity }\end{array}$ & $\begin{array}{c}\text { Freshwater } \\
\text { Ecotoxicity }\end{array}$ \\
\cline { 2 - 6 } & $\mathbf{( \mathbf { k g ~ C O } _ { \mathbf { 2 } } \mathbf { e } )}$ & $\left.\mathbf{( k g ~ S O}_{\mathbf{2}} \mathbf{e}\right)$ & $\left.\mathbf{( k g ~ P O}_{\mathbf{4}} \mathbf{e}\right)$ & $\mathbf{( k g ~ 1 , 4 - D B e )}$ & $\mathbf{( k g} \mathbf{1 , 4}-\mathbf{D B e )}$ \\
\hline N100 & 11,150 & 3.80 & 0.0784 & 260 & 1.98 \\
$\mathrm{~N} 80+\mathrm{NE20}$ & 11,190 & 3.79 & 0.0681 & 247 & 1.78 \\
$\mathrm{~N} 60+\mathrm{NE40}$ & 11,240 & 3.77 & 0.0578 & 234 & 1.57 \\
$\mathrm{~N} 50+\mathrm{NE50}$ & 11,260 & 3.76 & 0.0527 & 227 & 1.4705 \\
N40 + NE60 & 11,290 & 3.75 & 0.0476 & 220 & 1.3690 \\
N20 + NE80 & 11,330 & 3.73 & 0.0373 & 207 & 1.1660 \\
NE100 & 11,380 & 3.72 & 0.0270 & 194 & 0.9630 \\
\hline
\end{tabular}

This study could be used to identify the main hotspot, which could be helpful for farm management. For example, if there is a need to expand organic rice farming to the North, promotion of reduction in organic fertilizer (pellet) is required by using other choices, such as liquid organic fertilizer and cattle manure, which have lower impacts. In contrast, if expanding to Northeast, the alternative wet and dry rice cultivation method could be promoted to improve water management efficiency. Crop rotation, intercropping, and non-invasive cover cropping are also recommended to improve nutrient management and soil fertility. In addition, soil analysis, such as for $\mathrm{pH}$ and nutrients in soil, is suggested for both areas for higher nutrient use efficiency, resulting in the reduction of fertilizers, investment costs, and environmental impacts.

It was also highlighted that the main hotspot for GHG emissions was largely linked to the direct methane emissions from rice fields, where the impact reduction must be focused. It is worth mentioning that the emission factors were obtained from both direct measurements where the data were available, which turned out to be higher than the default values based on the IPCC-Tier 1 method. Therefore, there is a need to develop the baseline emission factors of different rice farming systems in Thailand to reflect more realistic data in terms of GHG emissions. The other factors affecting the methane emissions were linked to the application of different organic fertilizers and soil quality. The study on the linkage of soil quality and GHG emissions should also be combined with the results from LCA. In addition to that, several factors are linked to the rice farmers' decision to adopt organic rice production. Yanakittkul and Aungvaravong [40] highlighted that attitudes towards farming behavior, group-norm influences on farming behavior, perceived behavioral control of farmers, comparative usefulness of behaviors, perceived of risk of farming, and support of government policy were the key factors. Especially for small-scale holders, governmental support for (1) irrigation efforts for organic 
rice farming (e.g., digging ponds, wells, pumping stations), (2) the prices of certified organic rice, (3) organic rice exports, (4) production equipment acquisition (e.g., seed, organic fertilizer, and organic rice mills), (5) low-interest loans for organic rice farmers, (6) assistance for farmers to certify organic rice standards, and (7) cultivation knowledge and techniques to increase the productivity of organic rice is needed.

\section{Conclusions}

Organic rice is expected to be a solution for sustainable agriculture, as it damages the ecosystem's health less than conventional rice and promotes human health. From the ecosystem approach, growing organic rice with no use of chemicals, pesticides, and herbicides could potentially improve the soil fertility and biodiversity. However, chemical use is not the only environmental aspect to consider. Direct GHG emissions from rice fields and agricultural activities of organic rice farming practices could also have impacts on the environment. This work carried out an analysis of the national policy of expanding organic rice cultivation areas by assessing the cumulative environmental performance of organic rice at the regional and national levels. Different scenarios created by varying different ratios of possible areas for organic rice expansion, representing alternative policy options, were proposed and investigated. The system approach and quantitative life cycle environmental impacts resulting from the LCA study were primarily introduced to support the policy decisions in Thailand. The cumulative environmental impacts from the nine provinces in the North turned out to be lower than those from the 12 provinces in the Northeast, due mainly to their higher yields and lower use of fertilizers. The rice farmers in the North also have the advantage of irrigation systems, while the rice farmers in the Northeast are mainly in rain-fed areas. This information could be useful for supporting the policy decisions about the areas in which organic rice farming should be expanded to minimize the potential life cycle environmental impacts. It was worth mentioning that the LCA was performed under the assumptions made, and, therefore, the LCA results should be treated under those limitations to focus on the environmental aspects only. The policymakers must also consider other factors affecting the promotion of organic rice, especially from the socio-economic perspectives.

Author Contributions: R.M. is the principal researcher involved in the research development, the data collection, the validation of collected data, the data analysis, and conclusions of the results, including leading the writing of manuscript. S.S. and S.D. conducted the data collection and data analysis. S.H.G. helped with the data analysis, data validation, and reviewing the manuscript. All authors have read and agreed to the published version of the manuscript.

Funding: This research was funded by the National Science and Technology Development Agency (Thailand) Special thanks are given to the rice farmers for their good cooperation.

Conflicts of Interest: The authors declare no conflict of interest.

\section{References}

1. FAO. Implementation of the World Food Summit Plan of Action. 2020. Available online: http://www.fao.org/ 3/w9990e/w9990e07.htm (accessed on 10 July 2020).

2. Willer, H.; Schlatter, B.; Trávní cek, J.; Kemper, L.; Lernoud, J. The World of Organic Agriculture-Statistics and Emerging Trends; FAO: Rome, Italy, 2020.

3. FIBL. Organic World. 2019. Available online: https://www.organic-world.net/country-info/asia.html (accessed on 19 January 2019).

4. Ferreira, G.; Skorbiansky, S.R. Commodity Focus: Overview of the U.S. Organic Rice Market. In Rice Outlook No. (RCS-18G); Economic Research Service, USDA: Washington, DC, USA, 2018.

5. Azadi, H.; Schoonbeek, S.; Mahmoudi, H.; Derudder, B.; De Maeyer, P.; Witlox, F. Organic agriculture and sustainable food production system: Main potentials. Agric. Ecosyst. Environ. 2011, 144, 92-94. [CrossRef]

6. FAO. Organic Agriculture. 2019. Available online: http://www.fao.org/3/X0075e/X0075e.htm (accessed on 19 January 2019).

7. Lotter, D.W.; Seidel, R.; Liebhardt, W. The performance of organic and conventional cropping systems in an extreme climate year. Am. J. Altern. Agric. 2003, 18, 146-154. [CrossRef] 
8. Marinari, S.; Mancinelli, R.; Campiglia, E.; Grego, S. Chemical and biological indicators of soil quality in organic and conventional farming systems in Central Italy. Ecol. Indic. 2006, 6, 701-711. [CrossRef]

9. Pimentel, D.; Hepperly, P.; Hanson, J.; Douds, D.; Seidel, R. Environmental, energetic, and economic comparisons of organic and conventional farming systems. BioScience 2005, 55, 573-582. [CrossRef]

10. Komatsuzaki, M.; Syuaib, M.F. Comparison of the Farming System and Carbon Sequestration between Conventional and Organic Rice Production in West Java, Indonesia. Sustainability 2010, 2, 833-843. [CrossRef]

11. Minasny, B.; McBratney, A.B.; Hong, S.Y.; Sulaeman, Y.; Kim, M.S.; Zhang, Y.S.; Kim, Y.H.; Kim, M.S.; Han, K.H. Continuous rice cropping has been sequestering carbon in soils in Java and South Korea for the past 30 years, Global. Biogeochem. Cycles 2012, 26, 3. [CrossRef]

12. Fei, L.U.; Xiao-Ke, W.A.N.G.; Bing, H.A.N.; Zhi-Yun, O.; Hua, Z. Straw return to rice paddy: Soil carbon sequestration and increased methane emission. Chin. J. Appl. Ecol. 2010, 21, 99-108.

13. Zhang, W.; Xu, M.; Wang, X.; Huang, Q.; Nie, J.; Li, Z.; Li, S.; Hwang, S.W.; Lee, K.B. Effects of organic amendments on soil carbon sequestration in paddy fields of subtropical China. J. Soils. Sediments 2012, 12, 457-470. [CrossRef]

14. Ghimire, R.; Lamichhane, S.; Acharya, B.S.; Bista, P.; Sainju, U.M. Tillage, crop residue, and nutrient management effects on soil organic carbon in rice-based cropping systems: A review. J. Integr. Agric. 2017, 16, 1-15. [CrossRef]

15. Yodkhum, S.; Gheewala, S.H.; Sampattagul, S. Life cycle GHG evaluation of organic rice production in northern Thailand. J. Environ. Manag. 2017, 196, 217-223. [CrossRef]

16. Harada, H.; Kobayashi, H.; Shindo, H. Reduction in greenhouse gas emissions by no-tilling rice cultivation in Hachirogata polder, northern Japan: Life-cycle inventory analysis. Soil Sci. Plant Nutr. 2007, 53, 668-677. [CrossRef]

17. Jimmy, A.N.; Khan, N.A.; Hossain, M.N.; Sujauddin, M. Evaluation of the environmental impacts of rice paddy production using life cycle assessment: Case study in Bangladesh. Model. Earth Syst. Environ. 2017, 3, 1691-1705. [CrossRef]

18. Hokazono, S.; Hayashi, K. Variability in environmental impacts during conversion from conventional to organic farming: A comparison among three rice production systems in Japan. J. Clean. Prod. 2012, 28, 101-112. [CrossRef]

19. Hokazono, S.; Hayashi, K. Life cycle assessment of organic paddy rotation systems using land- and product-based indicators: A case study in Japan. Int. J. Life Cycle Assess. 2015, 20, 1061-1075. [CrossRef]

20. Nunes, F.A.; Seferin, M.; Maciel, V.G.; Flôres, S.H.; Ayub, M.A.Z. Life cycle greenhouse gas emissions from rice production systems in Brazil: A comparison between minimal tillage and organic farming. J. Clean. Prod. 2016, 73, 799-809. [CrossRef]

21. Bacenetti, J.; Fusi, A.; Negri, M.; Bocchi, S.; Fiala, M. Organic production systems: Sustainability assessment of rice in Italy. Agric. Ecosyst. Environ. 2016, 225, 33-44. [CrossRef]

22. Lovarelli, D.; Bacenetti, J.; Fiala, M. Effect of local conditions and machinery characteristics on the environmental impacts of primary soil tillage. J. Clean. Prod. 2017, 140, 479-491. [CrossRef]

23. Fusi, A.; Bacenetti, J.; González-García, S.; Vercesi, A.; Bocchi, S.; Fiala, M. Environmental profile of paddy rice cultivation with different straw management. Sci. Total. Environ. 2014, 494, 119-128. [CrossRef]

24. Mungkung, R.; Pengthamkeerati, P.; Chaichana, R.; Watcharothai, S.; Kitpakornsanti, K.; Tapananont, S. Life Cycle Assessment of Thai organic Hom Mali rice to evaluate the climate change, water use and biodiversity impacts. J. Clean. Prod. 2019, 211, 687-694. [CrossRef]

25. Office of the National Economic and Social Development Board, Office of the Prime Minister. The Twelfth National Economic and Social Development Plan (2017-2021). 2019. Available online: https://www.greengrowthknowledge.org/sites/default/files/downloads/policy-database/THAILAND\%29\% 20The\%20Twelfth\%20National\%20Economic\%20and\%20Social\%20Development\%20Plan\%20\%2820172021\%29.pdf (accessed on 19 January 2019).

26. Office of Agricultural Economics. Agricultural Economic Information. 2020. Available online: http: //www.oae.go.th/view/1/Information/EN-US (accessed on 7 July 2020).

27. Department of Rice. Rice Production in Thailand. 2020. Available online: http://www.ricethailand.go.th/ web/home/images/brps/text2559/15092559/15092559.pdf (accessed on 7 July 2020).

28. International Organization for Standardization. Environmental Management: Life Cycle Assessment; Requirements and Guidelines; ISO: Geneva, Switzerland, 2006. 
29. International Organization for Standardization. Environmental Management: Life Cycle Assessment; Principles and Framework; ISO: Geneva, Switzerland, 2006.

30. Thailand Greenhouse Gas Management Organization (Public Organization) (TGO). Product Category Rules: Rice Products. 2018. Available online: http://thaicarbonlabel.tgo.or.th/PCR/A4.pdf (accessed on 20 July 2018).

31. Ohsodsapa, Y.; Vongmaneeroj, A.; Hongphayoon, C. Fertilizers for Sustainable Agriculture; KU Inc.: Bangkok, Thailand, 2008.

32. Sitthipasin, R.; Seedachakul, T. Compost production from agricultural residue. Res. J. CMRU 2009, 2, $103-105$.

33. Suthipasil, R.; Sridechakul, T. Organic Fertilizer (Pellet) Production from Agriculture Waste; Chiang Mai Rajabhat University Intellectual Repository: Bangkok, Thailand, 2006.

34. Region Environment Office 6 (REO6), Ministry of Natural Resources and Environment of Thailand. Bio-Ferment Juice and Bio-Compost. 2010. Available online: http://reo06.mnre.go.th/home/index.php? option=com_content\&task=view\&id=1220\&Itemid=264 (accessed on 19 June 2016).

35. Intergovernmental Panel on Climate Change. 2006 IPCC Guidelines for National Greenhouse Gas Inventories. 2006. Available online: http://www.ipcc-nggip.iges.or.jp./public/2006gl/index.Html (accessed on 28 April 2013).

36. Goedkoop, M.J.; Heijungs, R.; Huijbregts, M.; De Schryver, A.; Struijs, J.; Van Zelm, R. A Life Cycle Impact Assessment Method Which Comprises Harmonised Category Indicators at the Midpoint and the Endpoint Level; First Edition Report I: Characterization. 2009. Available online: http://www.lcia-recipe.net (accessed on 6 January 2016).

37. Thai Meteorological Department (TMD). Monthly Weather Summary [in Thai]. 2015. Available online: http://www.tmd.go.th/en/climate.php?FileID=4 (accessed on 20 March 2015).

38. Etiope, G. EMEP/EEA Air Pollutant Emission Inventory Guidebook 2009; EEA: Copenhagen, Denmark, 2009.

39. Land Development Department (LDD). Soil Classification in Thailand. 2019. Available online: http: //oss101.ldd.go.th/thaisoils_museum/survey_1/AboutCLASS_01_57.HTM (accessed on 19 January 2019).

40. Yanakittkul, P.; Aungvaravong, C. A model of farmers intentions towards organic farming: A case study on rice farming in Thailand. Heliyon 2020, 6, e03039. [CrossRef] [PubMed]

(C) 2020 by the authors. Licensee MDPI, Basel, Switzerland. This article is an open access article distributed under the terms and conditions of the Creative Commons Attribution (CC BY) license (http://creativecommons.org/licenses/by/4.0/). 